\title{
Archaeological Fakes and Forgeries in Turkey
}

\author{
Ergün Lafli * \\ Maurizio Buora**
}

LAFLI, E.; BUORA, M. Archaeological Fakes and Forgeries in Turkey. R. Museu Arq. Etn. 36: 1-21, 2021.

\begin{abstract}
In this paper we discuss archaeological authenticity in Turkey, advanced both from scholarly as well as popular scientific point of views. In the last five years in Turkey, the inconspicous debate on "archaeological authenticity" has become public. The problem was previously known, but not very common in scientific research. Turkish archaeologists probably a long way ahead to deal with this matter in scientific terms and accept it as an important study area. Although Turkey is a key country for both original and fake products, we know little about which materials should be categorized as replicas or fakes; which objects were falsified; what materials were falsified, why and by whom. The expected number of forgeries is very high in local museums exhibits, including lamps, coins, metal objects (especially silver) and gems. In international markets, we know several classes that have been forged in Turkey. It is particularly difficult to distinguish authentic coins or modern fakes. In the last ten years, Turkish museums were involved in several forgery scandals. These deceptions have two explanations: either the museum managers know nothing about them, or there are other reasons for these pieces to be presented as real artifacts. This paper presents a sampling catalogue for the reanalysis of the artifacts using multiple criteria to determine their non-authenticy.
\end{abstract}

Keywords: Archaeological fakes; Replicas; Imitations; Authentic; Turkish museums.

\section{Introduction}

Recently, in Turkey, many local collections have appeared since the 1980s, mostly through purchases. Also, the scientific staff of local museums in Turkey (Fig. 1.) was cut in half

\footnotetext{
* Professor of Classical Archaeology at the Dokuz Eylül University. To consult other publications by the author: <https:// deu.academia.edu/ErgunLAFLI>. <ergun.lafli@deu.edu.tr>

** Società Friulana di Archeologiam Udine. Ex-director of Civici Musei Udine. To consult other publications by the author: 〈https://independent.academia.edu/mauriziobuora>. <mbuora@libero.it>
}

(from 1500 to 750 archaeologists). This, combined with the natural human inclination for fraud and illicit gain, has encouraged the presence of copies and forgeries in museums. Antique dealers in Turkish museums from whom the products are purchased usually claim that they found them in ancient sites. This case study also raises questions concerning the use of unprovenanced objects as archaeological data in the archaelogical reconstruction of Asia Minor. 


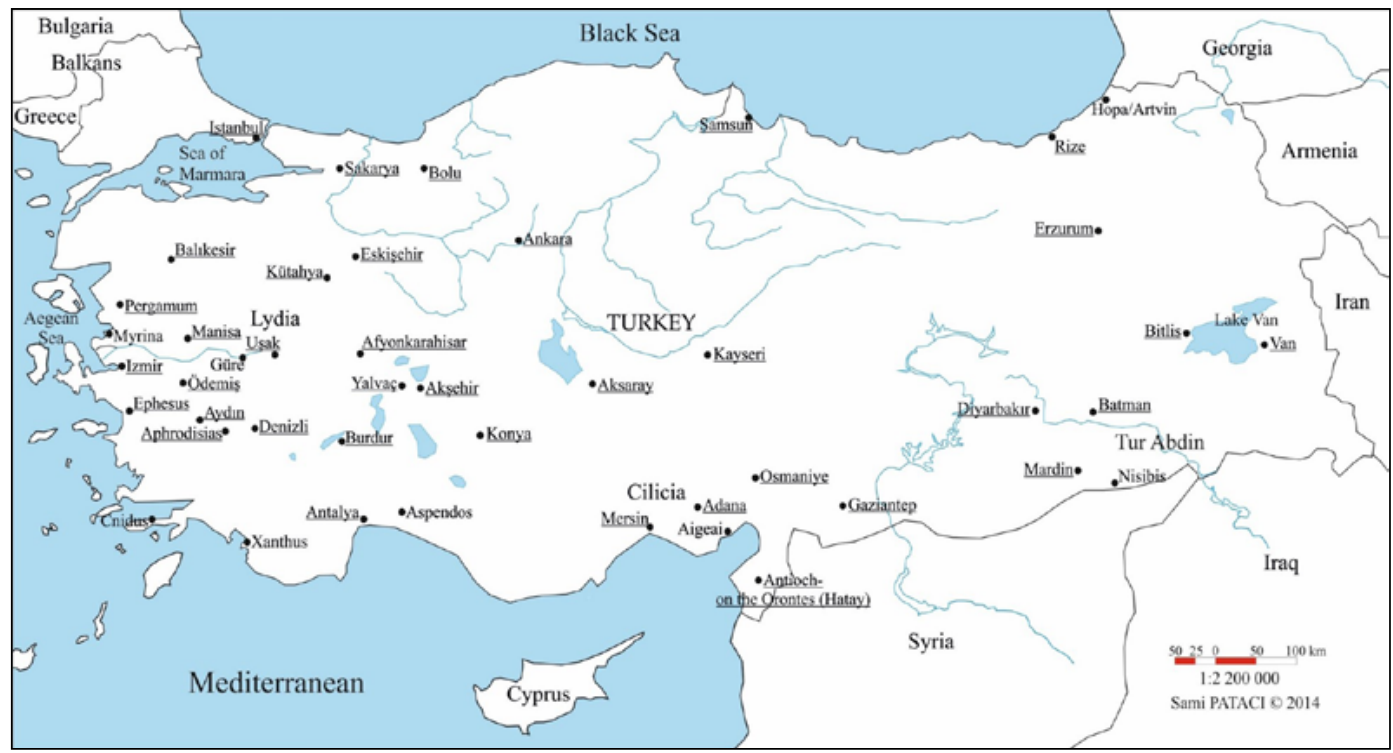

Fig. 1. Referred places in Turkey.

Source: Patac1 (2014).

The illegal trade of counterfeit antiques is considered by international police as third largest market after the human and drug trafficking (Bowman Proulx 2011: 192). In the last five years in Turkey, the previously inconspicuous debate on "archaeological forgery" has become public. This problem was previously known, but not common in academic research. It will probably still be a long way to go until Turkish archaeologists deal with this matter in scientific terms and accept it as an important study area. Although Turkey is a key country for both originals, as well as fake products, we know very little about which objects were falsified; what materials were falsified, why and by whom. Antiquities markets and the development of antiquarian studies in North America and Western Europe fueled the growth of cottage industries involved in the plunder of archaeological sites and forgery in Turkey.

In Turkey the number of forgeries in the local museums exihibts, including lamps, coins, metal objects (especially silver and gold) and gems, is higher than estimated. In international markets we are aware of several archaeological items that have been forged in Turkey. It is particularly difficult to distinguish original and false coins. How to distinguish the real ones from the fake? Of course, the study of the material should be the first step. Archaeologists know which marble sources ancient artists were accustomed to use, depending on the area and time, and the ancient alloys of the metals are also known. The deceptions have two explanations: either the museum authorities know nothing about them, or there are other reasons that they are presented as real exhibits.

In the Turkish collections many objects seem deceptively realistic. Through scientific methods, such as thermoluminesce dating, radiocarbon, neutron activation or X-ray fluorescence analysis, magnetometric investigations etc., it is possible to determine the age, composition, or the authenticity of an archaeological artifact and also disclose the structure and composition of the metal. Recently, archaeological forgeries are unmasked especially by chemical analyzes (Aydın 2013a: 170-171; Aydın 2013b; Craddock 2009: 7-8; Mezzasalma et al. 2009): all ceramic materials store radioactive radiation that comes from natural uranium, thorium and potassium. This low radioactivity can be visualized as lights when heating the material to about 500 degrees Celsius (Spier 1990: 624-625). 
By whom and for what reason archaeological objects are falsified? Most counterfeits in the world originate from regions that still have neither sophisticated analysis, nor enough knowledge of the materials and manufacturing methods - eg. in Western Africa and China, but also in southern Italy, Greece and Turkey (Holtorf 2013: 429). In Turkey, the traditional craft still dominates ${ }^{1}$. Usually it involves mass production of relatively low value; forging pieces with high scientific value is not worth it. The activity of Turkish counterfeiters nowadays has some mafialike features. In these groups, the forgeries are indeed more professional, but for archaeologists it is still possible to expose all doubt, without knowing their origin. In the following sections we will present some fake items from Turkey, according to their archaeological genres. The main sources of material are local archaeological museums.

The improvement in people's culture together with the progressive increase in the standard of living have made collecting more "democratic", even though in past centuries it was limited to a few examples of the ruling classes (Brodie, Doole \& Renfrew 2001: 6). We refer to the collecting of antiquities - that often has benefited from the poor economic conditions of former rich lands, - born in the courts, which has expanded to the nobility since the Renaissance (Brodie \& Renfrew 2005: 245). The opening of large museums made them successors in the demonstration of power that was previously reserved for the royal collections. So, many of them did not hesitate to transfer their archaeological collections from other countries, often acquired through excavation or in the antiquarian trade. It is hardly necessary to mention the Elgin Marbles ${ }^{2}$ in the British

1 In the newspaper Bugün on March 23, 2014 a Turkish counterfeiter is introduced extensively who worked mostly with traditional methods. This could be a comparison to a German counterfeiter: Neidhardt (2010).

2 The Elgin Marbles, also known as the "Parthenon Marbles" are a collection of classical Greek marble sculptures (mostly by Phidias and his assistants), inscriptions and architectural members that originally were part of the Parthenon and other buildings on the Acropolis of Athens. Thomas Bruce, the 7th Earl of Elgin obtained a controversial permit from the Ottoman authorities to
Museum, but much more significant for Turkey is the case of the Zeus Altar from Pergamum in Berlin ${ }^{3}$. In this task North American museums are remarkable, because since the end of the nineteenth century they did not spare any expenses to acquire items legally or illegally (Brodie, Doole \& Watson 2000: 23-24; Renfrew 2002: 16). The Metropolitan Museum of Art has a long history in this regard, but there are other North American collections, such as the J. Paul Getty Museum in Malibu or the Dumbarton Oaks in Washington, DC. In the major auction houses in Switzerland, Great Britain or the U.S. objects from clandestine excavations have been auctioned several times.

As mentioned, the other major public western collections contain forgeries and falsifications: on the website and in publications of the British Museum ${ }^{4}$ we can see many of them; ranging from sculpture to pottery to intaglios. In this short review we will present some cases related to museum collections in Turkey.

remove pieces from the Parthenon while serving as the British ambassador to the Ottoman Empire from 1799 to 1803. From 1801 to 1812, Elgin's agents removed about half of the surviving sculptures of the Parthenon, as well as architectural members and sculpture from the Propylaea and Erechtheum. The Marbles were transported by sea to Britain. In Britain, the acquisition of the collection was supported by some, while some critics compared Elgin's actions to vandalism or looting. A public debate in Parliament and the subsequent exoneration of Elgin's actions, the marbles were purchased by the British government in 1816 and placed on display in the British Museum, where they stand now in the purpose-built Duveen Gallery. The debate continues as to whether the Marbles should remain in the British Museum or be returned to Athens.

3 In 1878, the German engineer Carl Humann began official excavations on the Acropolis of Pergamon, an effort that lasted until 1886. The excavation was undertaken in order to rescue the altar friezes and expose the foundation of the edifice. Later, other ancient structures on the Acropolis were brought to light. Upon negotiating with the Turkish-Ottoman government, it was agreed that all frieze fragments found at the time would become the property of the Berlin museums. In Berlin, Italian restorers reassembled the panels comprising the frieze from the thousands of fragments that had been recovered. In order to display the result and create a context for it, a new museum was built in 1901 on Berlin's Museum Island.

4 The British Museum (2007). 


\section{Cuneiform tablets}

The first cuneiform forgeries of modern times appear in the collection of Claudius James Rich (1786-1821), created before cuneiform had been deciphered (Jones, Craddock \& Barker 1990: 165). "By 1904, during the early period of cuneiform tablet collecting, J. Edgar Banks, a Mesopotamian explorer and tablet dealer, estimated that nearly $80 \%$ of tablets offered for sale in Baghdad were fake" (Brumfield 2018). In 2016, Syria's Antiquities General Director and Museums reported that approximately $70 \%$ of seized artifacts in the country are fake. In 1987 Christopher B. F. Walker wrote that "a large number of fakes [was] made in Turkey in the early years of this century [namely $20^{\text {th }}$ century] it is remarkable how many tablets still circulate in the market today" (Walker 1987: 59-60).

\section{Stone statues, statuettes, sarcophagi and mosaics}

The creation of sculptures in stone are the most difficult to counterfeit because the equipment used in the ancient world is missing. However, the marble quarries, such Docimium and Synnada in Phrygia have remained the same (Barresi 2003; Pensabene 1998). Today, Phrygia provides the same marble as two thousand years ago.

The small-scale Phrygian marble statuettes, which were intended for domestic cult, are imitated the most, as well as the gods of the Roman pantheon. For a precise stylistic analysis, one sees that the statuettes of local museums in Phrygia are selected as models (an original Hercules' statue from the USA was replaced by a fake from the Museum of Afyonkarahisar), eg. Uşak, Denizli and Kütahya ${ }^{6}$.

5 In the Museum of Afyonkarahisar there are two fake Byzantine seals; cf. Bulgurlu \& İlaslı (2003: 131).

6 On the Kütahya fakes cf. Colomban, Laveaucoupet \& Milande (2005).
The marks on the surface should be enough to see that the modern stonemasons used modern equipment. Sometimes the surface is made older by artificial patina and even buried for some time in the earth. In such cases the surfaces and style usually look very artificial. Most of these forgeries have something ambivalent and caricatural, and they lack harmony. In recent years, the number of counterfeit sarcophagi and osthotekai is rising. There are copies of well-known compositions of individual detailed figures from well-known representations.

Although it is quite difficult to counterfeit a mosaic, there are several attempts in Turkey. The mosaics of the southern provinces, such as Gaziantep and Hatay, were forged particularly often. Mostly the wrong use of the stone or the abscence of real paint, place the authenticity into question (cat. no. 17).

\section{Bronze statues and statuettes}

Most of the bronze statues from Asia Minor are found underwater, together with sunken ships in the sea. The discovery of bronze statues in certain archaeological contexts is rare. The poured bronze seems to be attractive to the counterfeiters. The proportions of bronze works are often not appropriate. The bronze patina cannot be copied; therefore, the surface of fake objects looks more polished, and the traces of modern casting techniques can even be felt. Because other casting techniques are used, modern objects are heavier than the ancients. In small-sized figures the same errors occur; today at the small-scale figurine the tracks are not easy to remove. This is precisely why it is so difficult to recognize real from fake. The ideal sculpture is often selected as model of the larger bronzes.

\section{Terracottas}

In western Asia Minor there are several large centers of coroplastic production, such as Myrina and Smyrna in the Hellenistic period; in Roman times many of these works were copied, especially in Phrygia. The Phrygian terracottas, 
which imitated the Hellenistic models, were admired just as the Myrinaean terracottas (Pottier \& Reinach 1888: 165-166; Uhlenbrock 1990: 27). During the 19th century the flood of Tanagra counterfeit began. In modern times such terracottas, especially Aphrodite (cat. nos. 18-20) and female figures are often falsified. The modern forgeries of terracottas are heavier than the originals. The colors look very artificial. The burning hole is usually omitted; the outer surface does not match the tone of the true figures. The simple Phrygian terracotta are usually falsified (Fig. 19 and 20). In coroplastic objects, the aesthetic difference between a deceptive forgery and an originalpiece is large.

\section{Bronzes, pottery, glass and miscellaneous}

Bronze vessels are forged in Turkey very often; lamps are the most popular genre. However, modern copies are unmasked because of modern casting techniques.

Pottery is also frequently imitated, but modern archaeometric techniques easily detect false objects. The fake vases produced in Turkey are rarely convincing because they cannot imitate ancient clay, and the pieces are usually quite raw. In the grooves of a fake Cnidian vessel, for example, a green powder (copper nitratea watersoluble salt) can be found (Fig. 21). Numerous oil lamps and unguentaria are also known by their imitations. For such objects, the counterfeiters produce an artificial corrosion layer by vapor deposition with nitric acid.

Glass is also falsified; but the production technology raises a problem regarding color recognition.

Gold, silver, and bronze earrings are often falsified; the biggest problem here is also that the former production techniques are not easy to imitate. Some imitations combine antique jewellery with modern stones.

Gems and glass jewellery are usually amateur counterfeits and easy to distinguish from authentic samples. Even minor metal instruments, such as fibulae and arrows are imitated. Byzantine Christian liturgical objects are very popular lately and falsified quite often.

\section{Coins}

In Turkey, most falsified objects are Greek and Roman coins, particularly in gold and silver. Both the pattern of the letters and the style of presentation are key factors for the authenticity of the coins; still there are lots of fake coins in Turkish collections. A crucial factor to identify counterfeited coins is the study of patina, a deposition layer formed by environmental influences on archaeological finds over the centuries (Sayles 2001: 2). The corrosion layer is difficult to reproduce. Other relevant factors are gold or silver content and the correct reproduction of the standardized shares used during the Classical Antiquity. The counterfeit Turkish coins have seam on the edge, bubbles, wrong weight, and a soapy contour. The fake coin is made as in antiquity with two embossing sticks. The embossing dies are either casts of the original or engraved by the forger. The embossed rays are tiny; radial grooves in the field between portrait and edge occur in gold and silver coins. They are particularly strong between legend and border. They can also have a wave-like shape. The embossed rays originate from the process of coinage.

Forgeries have a thin seam on the edge that must be removed. The resulting marks are almost always recognizable. Sometimes the seam is irregular. Some edges are slightly torn and after cooling, earth is pressed into these cuts to convey the feeling that the coin was found in the ground.

In false coins, the boundary point lines are often too sharp or the edge rim, which arises during the embossing process, is missing. Soft, fuzzy, "soapy" contours are clear indicators of falsification. Counterfeiters rarely imitate the die created by Roman artists with all the ornate details.

The most important aspect of counterfeit coins from Turkey is the style. Often the facial expression, the folds of the fabric, the letters or the position of the eyes do not match the original. Draping and letters are particularly difficult to falsify. In some of them too much precision could be an indication of a counterfeit, which could be interpreted as "too good to be true". 
In contrast to some bronze coins, Roman coins of precious metals were made in narrow moving confines, with standardized weight. Counterfeits rarely have exactly the desired weight. In the casting process, for example, the weight cannot be adjusted because the volume is fixed. The casting produces small bubbles on the surface of the coins. The field of real coins, except for embossed rays and mechanical damage, remain always smooth and even, if no corrosion is present. Embossed coins shrink when cooled slightly. This means that all modern embossing dies are slightly too small.

\section{Conclusion}

In counterfeits made in Turkey, it is often unclear when and who produced them. Turkish museums do not traditionally discuss their false artifacts, frankly in order to avoid the embarrassment that they have been deceived and to maintain public faith in museum expertise. The heist of 2006 marked a revolutionary change in Turkey. The Turkish Ministry of Culture and Tourism has been working to protect artifacts and to ensure that they are properly and safely displayed. Turkey has so far repatriated up to 3,700 stolen artifacts from foreign countries in the last seven years. There is, fortunately, an international trend to combat the looting of antiquities (Atwood 2004; Bowman Proulx 2011, 2013; Brodie \& Renfrew 2005; Brodie \& Tubb 2002; Renfrew 2002; Brodie, Doole \& Renfrew 2001). Obviously the first requirement is to convince the population that the plunder should be abolished because it impoverishes national heritage?

To compare forgeries, the General Directorate of Cultural Heritage and Museums of Turkey has prepared a database on fake objects $^{8}$. For this reason, an official website

7 "In some cases, looters threaten farmers who would inform the government of an ancient site" (Bower 2009: 23).

8 In this website there are five categories of fake items in Turkish museums: coins, statues, small finds, pottery and miscellaneous. Available from <https://bit.ly/2HQII7W〉. Acess in: 07/04/2020. following the model of Art Loss Register (ALR) ${ }^{9}$ was created and adopted by other countries such as Cyprus. A challenge for the future would be to include all known counterfeits in Turkey in a catalogue and to examine them in detail.

\section{Catalogue of the examples of archaeological fakes and forgeries in Turkey}

\section{A cuneiform tablet}

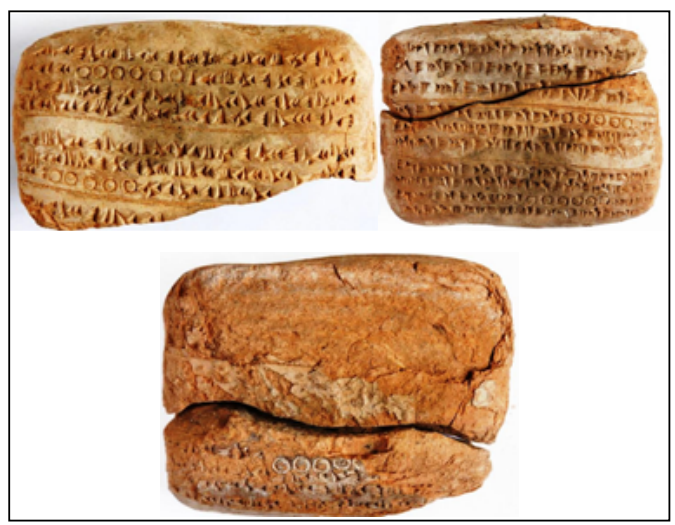

Fig. 2. A "Babylonian" cuneiform tablet.

Source: Archaeological Museums of Istanbul.

According to Christopher B. F. Walker an "excessive repetition of a small group of signs (in this case small circles) is also a common mark of an unimaginative forger" (Walker 1987: 60).

9 The Art Loss Register (2007) and the Turkish version: T.C. Kültür ve Turizm Bakanlığ 
Statues, statuettes, sarcophagi and mosaics

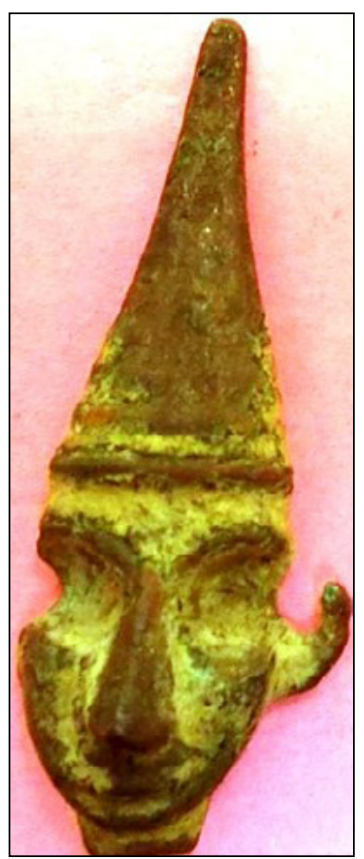

Fig. 3. A bronze "Hittite" miniature bust.

Source: Museum of Osmaniye.

The conical hat, big eyes, nose, massive, long, and protruding ear (broken) relate this head to the Syro-Hittite depictions of the deities, as the local Baal (Negbi 1976: 34-36). They are generally dated to the thirteenthtwelfth centuries B.C. In this case, the statue is poorly detailed, such as the large sunken eyes, and was made in schematic way by someone who is not familiar with the ancient specimens. Perhaps it is a copy of the bronze bust of Hurrian-Hittite God Tešup, preserved in the Museum of Amasya.

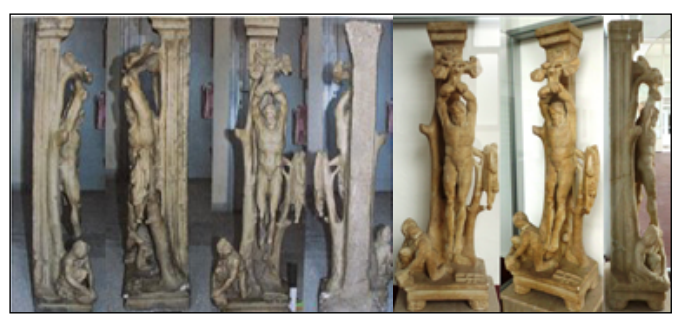

Fig. 4. Statue of Marsyas. Gray marble. Source: Museum of Balıkesir.
It is a copy of an original statue of the Museum of Manisa (Fig. 4) ${ }^{10}$, though the surface colour is black instead of white ${ }^{11}$. Another falsification of the same sort of Marsyas, with the same size and workmanship, is at the Museum of Eskişehir.

A large number of copies of the so-called "white Marsyas" was in circulation; so far 59 copies of Marsyas have been published. The "red Marsyas", named after the purple-veined marble used in the examples, derived from it ${ }^{12}$. The choice of material probably intended to give his flayed skin appropriate colouring.

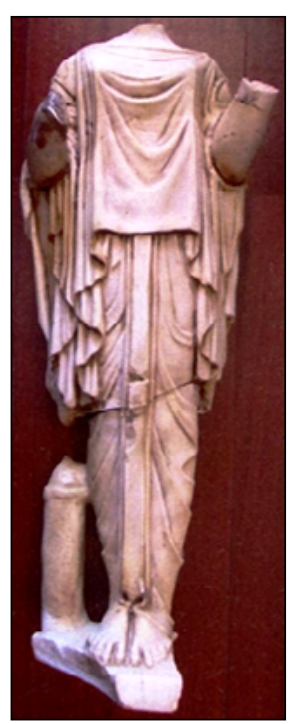

Fig. 5. A "Roman" statue of an Archaistic kore. H $67 \mathrm{~cm}$. White marble. It consists of two fragments; head is missing. Moulded.

Souce: Museum of Burdur.

10 The original Marsyas at the Museum of Manisa was obtained through illegal digs in the Village of Ballaca near Sarıgöl, in the Province of Manisa, ancient Lydia, in 1987. Shortly after it was transported out of Turkey and eventually Turkish authorities demanded this marble statue from the Atlantis Antiquities in New York in 1994. Cf. Turkish news about its return to the Museum of Manisa: T.C. Kültür ve Turizm Bakanlığ 1 (1994).

11 On the copies of the Marsyas see Weis (1992 appendix A)

12 On "white" and "red" Marsyas cf. Sismondo Ridgway (2002: 86-87); and on their distribution (white and red), between East and West, see Porter (2006: 152). 
The left arm is too big and protrudes unnaturally. The lower part of the figure is too narrow, and the feet have divergent toes. The drapery is completely different from classical art.

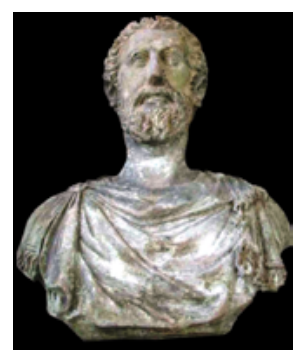

Fig. 6. Bronze portraif of Marc Aurel. $50 \times 40 \mathrm{~cm}$. Source: Museum of Kayseri.

The torso, almost life-size, shows an emperor in civic clothes. Thus, it would be a suitable representation at the center of a Roman city. The head is like that of the equestrian statue of the Capitoline Museums in Rome. However, the mustache is thicker, and his beard is made in a summary manner. Typically, this element is always made with care and attention even in small-scale bronzes, given the importance of the beard as a "philosophical" trait of the emperor, especially common in provincial military contexts. The model may have been copied from a marble bust of Ephesus (Witschel 1995: 260, no. 24).

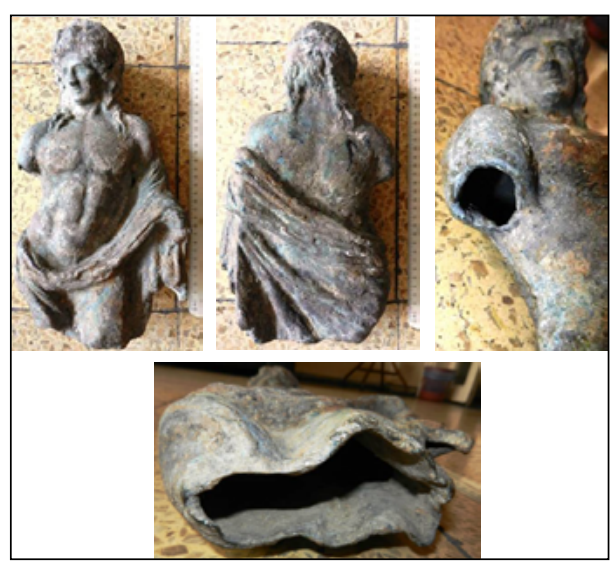

Fig. 7. Bronze statuette of Apollo. H $35 \mathrm{~cm}$. Fragmented. Source: Museum of Konya.
Free standig Apollo with the head turned to his right. The upper part of the body is bare, while the lower one is draped with the folds of a mantle. It is similar to the one at Hermitage Museum. The pectoral muscles in his chest are identical, as well as the overall design. But the craftsman did reproduced the hair and the drapery on the left leg well. The traces of modern fusion, visible on the edges of the broken part obviously on purpose - remove all doubts.

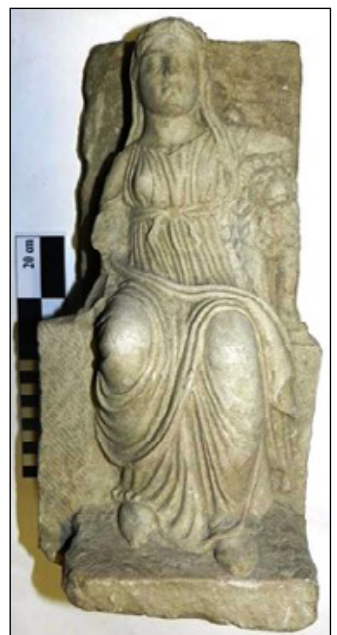

Fig. 8. Sandstone statue of a seated Cybele. $37 \times 17 \times 17 \mathrm{~cm}$.

Source: Museum of Sakarya.

The model seems to be a statue of the enthroned goddess from the Hellenistic period, now in the Museum of Anatolian Civilizations in Ankara. But we can see a lion on her left side, a quite unusual position: usually it lies at the foot of the goddess.

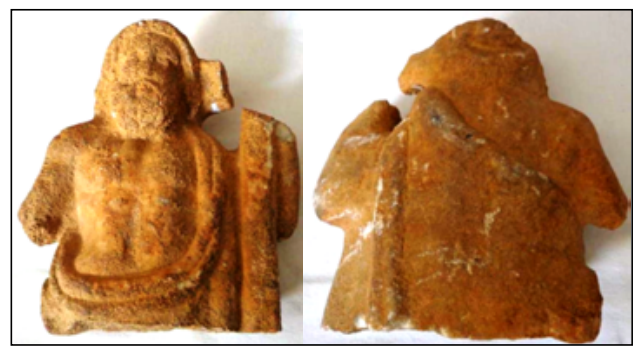

Fig. 9. Iuppiter. Marble. Fragmented.

Source: Museum of Anatolian Civilizations at Ankara. 
The producition of the face, hair and finally his anatomy is absolutely childish. The drapery is schematic and quite coarse.

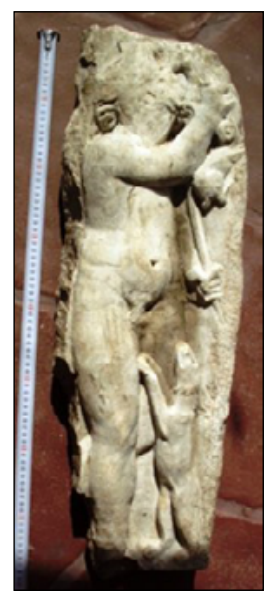

Fig. 10. Eros relief with a dog. Marble. Fragmented. Source: Museum of Manisa.

We see some problems in the bent of the arm and in the transition from the torso to the leg. The right leg is quite coarse, and the dog is amateurish.

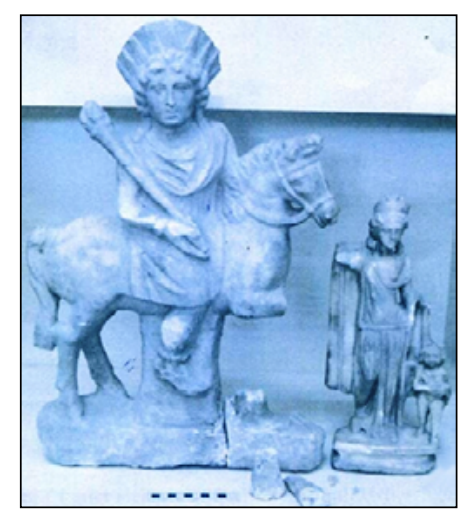

Fig. 11. Helios on horseback and a statuette of Aphrodite. Helios: H $58 \mathrm{~cm}$, W $40 \mathrm{~cm}$; Aphrodite: H $37 \mathrm{~cm}$, W $18 \mathrm{~cm}$. Both are marbles.

Source: Museum of Antalya.

Apart from the unusual depiction of the god as rider, we see here a clear influence of images of Helios with a crown of rays that appear in the early Hellenistic period, such as the chariot driver on the metope of the temple of Athena at Ilium, now in Berlin. In our statuette, the frontal presentation of the chest is quite unusual, while the lower part of the body is in prospect as in the Archaic art. It is also incoherent in the rendering of the right arm and especially of the horse. Note the expedient of making a fragmented work and presenting some scattered pieces. A terracotta image of Helios seated, with open arms, is preserved in the same museum in Antalya.

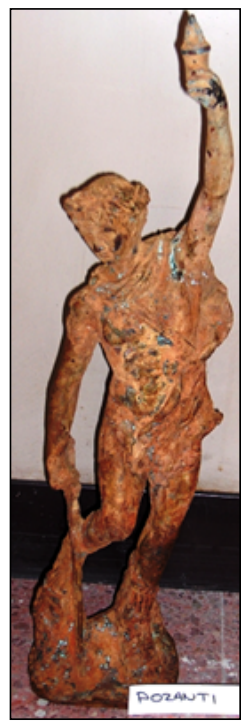

Fig. 12. Statuette of young man. From Pozant1, north of Adana. H: $51 \mathrm{~cm}$.

Source: Museum of Adana.

Young man, wearing a short dress, with the left hand holding up an object (a lantern?), supported by a stick in his right hand. He holds a bag (?), attached to a belt hanging from his right shoulder.

The patina is absolutely modern, the base is incongruous and some details, such as the left leg and arms, are different than the classical tradition. 


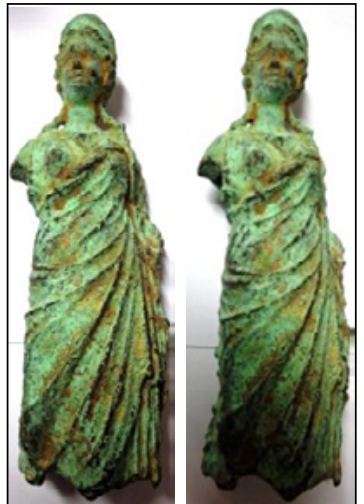

Fig. 13. Bronze statuette of a young woman.

Source: Museum of Anatolian Civilizations at Ankara.

Through the diadem she seems to be a goddess or empress. The braids remind the images of Agrippina the Elder. The patina is, however, very doubtful.

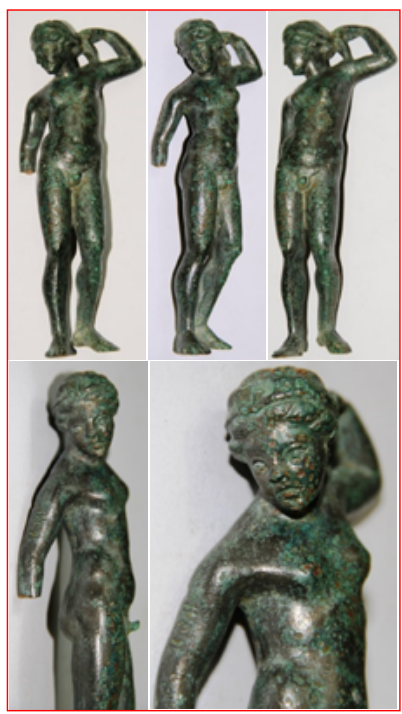

Fig. 14. Hermaphrodite. Inv. no. $1745 . \mathrm{H} 16 \mathrm{~cm}$, max. W 4,5 cm, min. W $3.5 \mathrm{~cm}$, weight $363,8 \mathrm{~g}$. Solid. Right hand missing from the joint. No evidence about the base. Green and brightish patina is overall on the surface. Pale brown false patina in various locations.

Source: Museum of Ödemiş.

Bronze alloy figurine of a standing nude male, wearing a hair ribbon with a visible band of wavy hair beneath. He stands facing with his head turned to the left, his left arm raised to his head and his left leg bent and slightly behind. His turning position shows an erotic perception, known in Aphroditic iconography. His missing right hand could have had a mirror, as featured in close parallels. He has small breasts that have been interpreted commonly as a "Hermaphrodite". The only genital indication for his gender is his penis. Aphroditic facial features are unusual as the eyes are too large and the nose does not fit the common forms ${ }^{13}$.

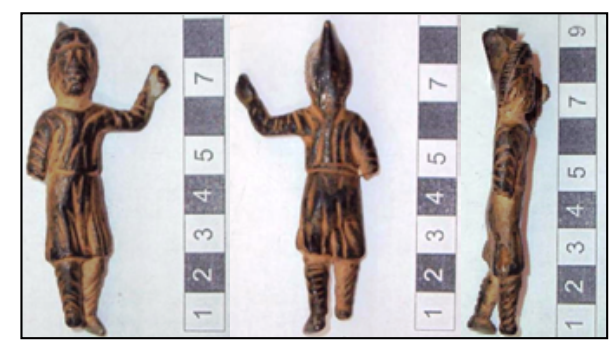

Fig. 15. Statuette of an Attis. H $8 \mathrm{~cm}$.

Source: Museum of Samsun.

The right forearm and hand are missing. It represents a common type, trivialized here in the headgear, in the folds of the robe, and in the legs. A work of little value.

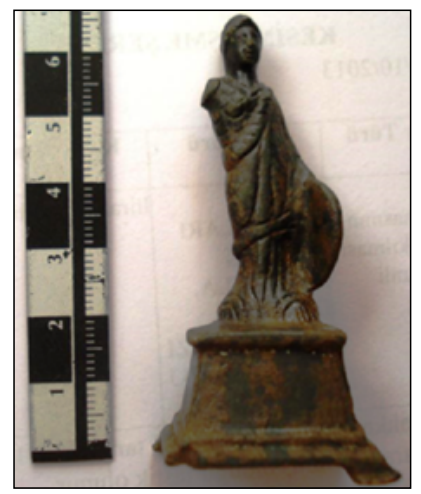

Fig. 16. Statuette of Athena. $7 \mathrm{~cm}$, base $2 \mathrm{~cm}$. Source: Museum of Konya.

13 Cf. Blanchet (1896 pl. 4), Babelon \& Blanchet (1895: 136, no. 307); Lasteyrie du Saillant (1890: 38, pls. VI-VII); and a similar at the British Museum with the accession number 1848,0803.44. 
Standing figure, lacking the right arm that would have to bear the missing spear, in the left hand she holds the shield.

On her chest the gorgoneion is made in a strange way. The base, unusual, is shaped like a truncated pyramid. The figure is unbalanced so that the eventual spear would fall out of the base. Some details are extremely simplistic, like the feet and the folds of the garment or the coarse draping.

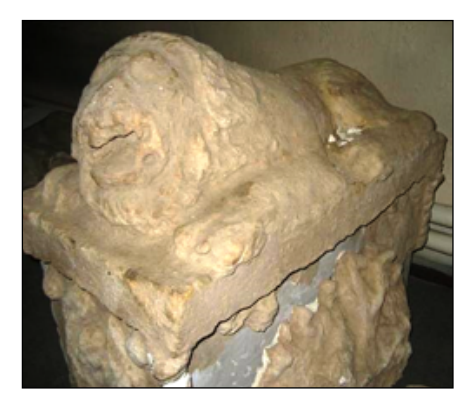

Fig. 17. Limestone ossuary. Fragmented. Source: Museum of Akşehir.

Lion on the lid, resting on the ground, with a large head and a circular manner. Pillars at the corners border relief scenes. A large fracture on its wall is filled with cement.

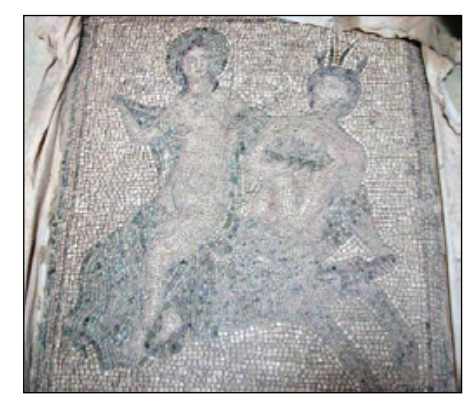

Fig. 18. Mosaic panel. $105 \times 90 \mathrm{~cm}$.

Source: Museum of Hatay.

The mosaic mixes the various elements of hierogamy of Dionysus and Ariadne - cf. for comparison the scene on the Derveni crater - that appears in the mosaics of Antioch. The colors are pale, and the execution is generally not accurate.

\section{Terracottas}

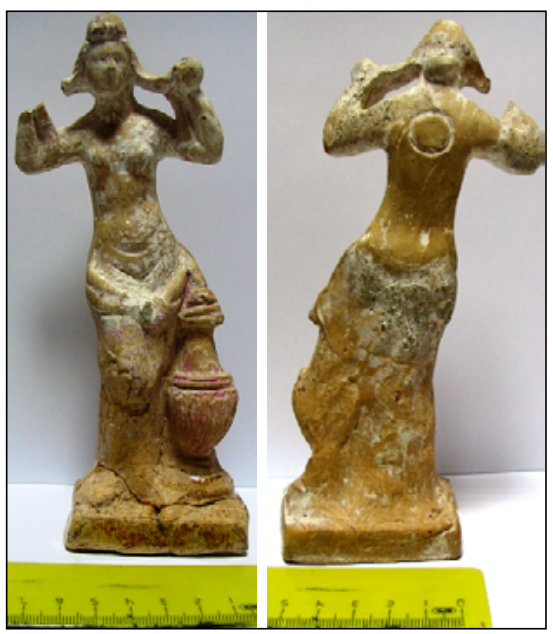

Fig. 19. Aphrodite. H $18 \mathrm{~cm}$, w $6.9 \mathrm{~cm}$, base $1.5 \mathrm{~cm}$. Source: Museum of Aydın.

Venus is shown standing and arranging her hair: similar to the previous one; the only difference is the vessel instead of a dolphin wrapped around the goddess. The dolphin is both in the so-called Mazarin Venus statue at the Getty Villa as in the life-size full-length white marble statue of Venus Anadyomene, also known as the Marine Venus, given to the Prince Consort by Queen Victoria as a birthday present on 26th August 1848, now in the Royal Collection London.

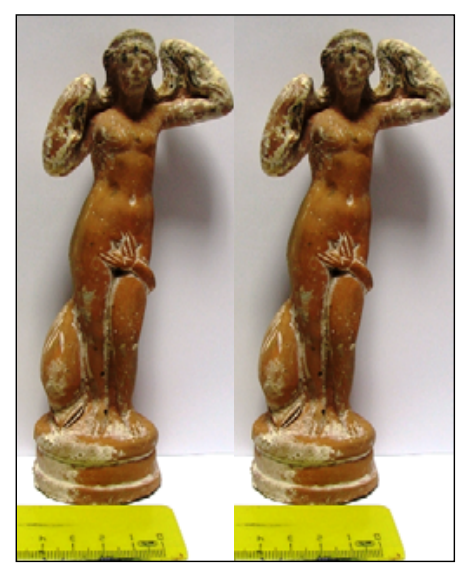

Fig. 20. Aphrodite. H $17.2 \mathrm{~cm}$, w $6.5 \mathrm{~cm}$, base $2.5 \mathrm{~cm}$. Source: Museum of Aydın. 
Archaeological Fakes and Forgeries in Turkey

R. Museu Arq. Etn., 36: 1-21, 2021.

The statue recalls a Hellenistic style made in Roman times, in small size, sometimes in painting and mosaic, characterized by the typical gesture of winging her hair. It can present, as in this case, a vase that supports the garments. Most statues of Venus were placed in the bathroom. This statue resembles a marble statue of Pompeii (Accademia Nazionale dei Lincei 1899: 206; Boyce 1937: 40 no. 118, note 1). In our case the figure is too oblique, as we can see in the back. The fact that it is a modern work is clearly indicated by the circular pseudohole in the back, which imitates the real old vent hole.

\section{Pottery}

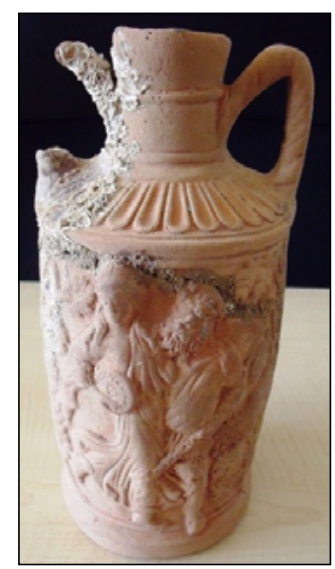

Fig. 21. "Cnidian" relief jug.

Source: Museum of Adana.

Terracotta jug or "oinophoros", inspired, or copied, from the British Museum 49-6-20.8 (Hayes 1972: 411-412). The original vessel was made at Cnidus, a trading and manufacturing port in Caria (southwestern Turkey). The relief decoration shows member of the Bacchic thiasos (a maenad and a silenus). The surface of the relief ware, smoothed with a stick finish, was covered by a reddish-brown slip, distinctive of Cnidian workshops when compared with Pergamenian productions. In our case, apart from the presence of chemical elements mentioned above, the rim and handles are different from the original (eg. the sample no. 49.94 .5 of the Metropolitan), while the base is similar.

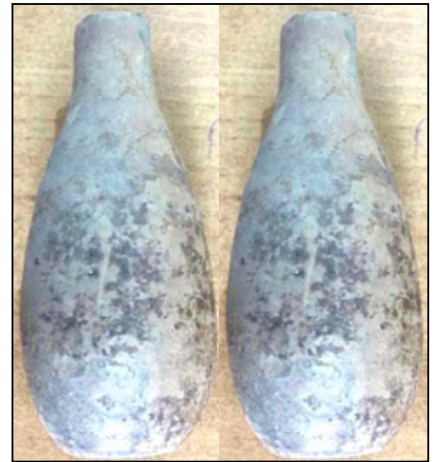

Fig. 22. Two terracotta unguentaria. From Sarayköy near Denizli. The slip does not correspond in any way to the true ointments.

Source: Museum of Denizli

Glass

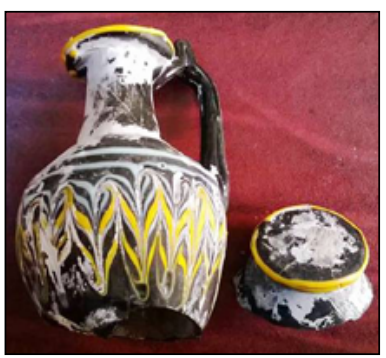

Fig. 23. Glass bottle. Broken bottom.

Source: Museum of Hatay.

The decoration on the neck is missing and the imitation of Phoenician glass is rough.

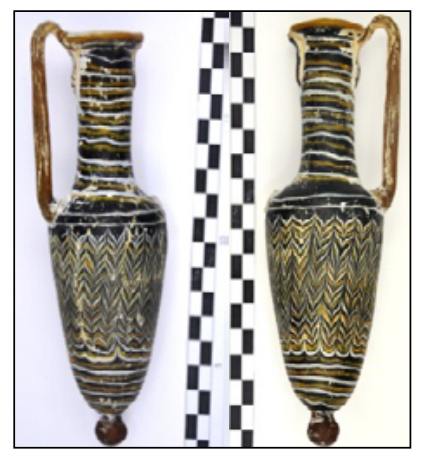

Fig. 24. "Phoenician" glass one handled amphoriskos. H $15.5 \mathrm{~cm}$, w 4.7 , rim r $3.1 \mathrm{~cm}$.

Source: Museum of Sivas. 
The handle, and the bands on the neck are very different from the original amphoriskoi.

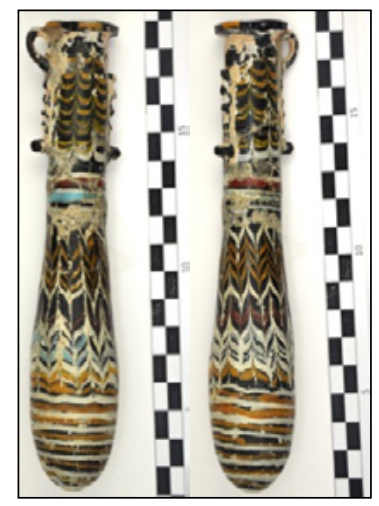

Fig. 25. "Phoenician" glass alabastra. H $15.5 \mathrm{~cm}$, W 4.7, rim r $3.1 \mathrm{~cm}$.

Source: Museum of Hatay.

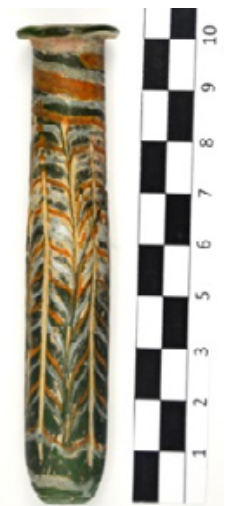

Fig. 26. "Phoenician" glass alabastra. H $9.1 \mathrm{~cm}$, W 1.5 , $\operatorname{rim} \mathrm{r} 1.9 \mathrm{~cm}$

Source: Museum of Hatay.

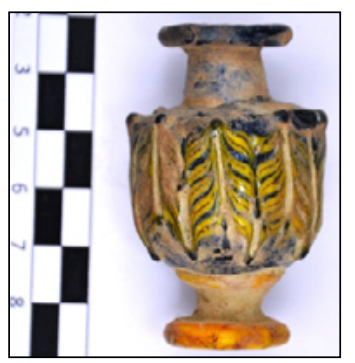

Fig. 27. "Phoenician" glass bottle. H $5.5 \mathrm{~cm}$, W 3.4, rim r $2.3 \mathrm{~cm}$, base $\mathrm{r} 2.1 \mathrm{~cm}$.

Source: Museum of Sivas.
Transcription (see eg. profile) to a wellknown form is uncertain.

The type of glass looks suspicious.

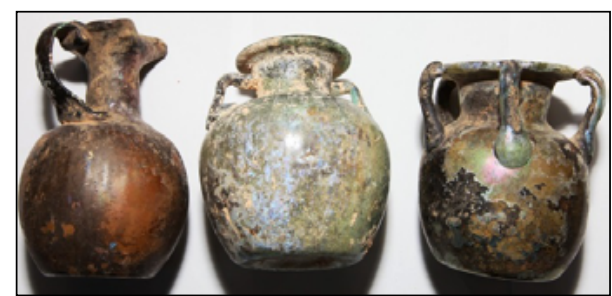

Fig. 28. Three glass bottles.

Sources: Museum of Hatay.

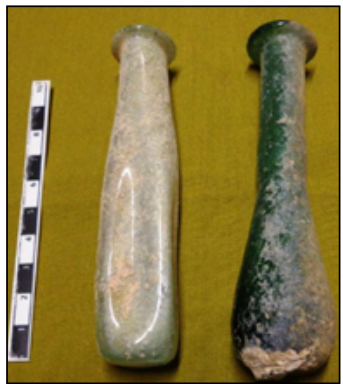

Fig. 29. Two glass bottles.

Souces: Museum of Anatolian Civilizations at Ankara.

The left bottle blends different shapes. The right one combines a type of Egyptian glass with an unusual shape in Egypt.

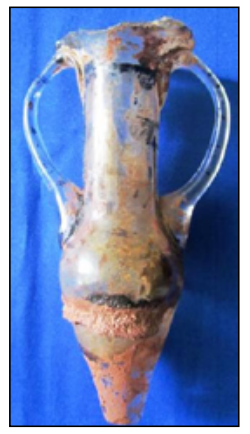

Fig. 30. Fusiform glass bottle.

Source: Museum of Bitlis.

An absolutely incongruous shape, unknown in Antiquity. 


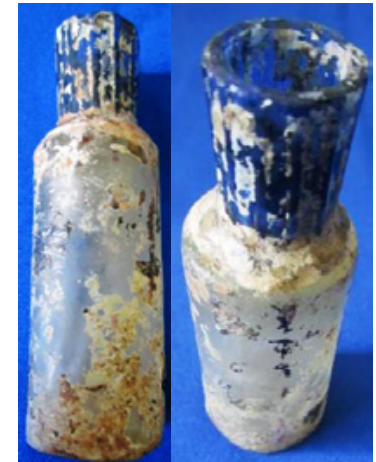

Fig. 31. Glass bottle.

Source: Museum of Bitlis.

The shape is reminiscent of Late Medieval Islamic glass, but the type of glass reveals the imitation.

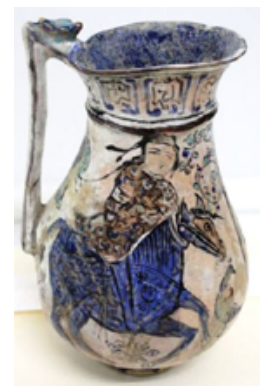

Fig. 32. One handled decorated glass jug. $\mathrm{H}$ $25.5 \times 25.9 \mathrm{~cm}, \operatorname{rim} \mathrm{r} 9.4 \times 10.2 \mathrm{~cm}$, body $\mathrm{r}$ $14.5 \times 15 \mathrm{~cm}$.

Source: Museum of Turkish and Islamic Arts at Istanbul.

A figure on horseback is reproduced that would look good on St. Simon pottery.

The color of the glass reveals a modern work.

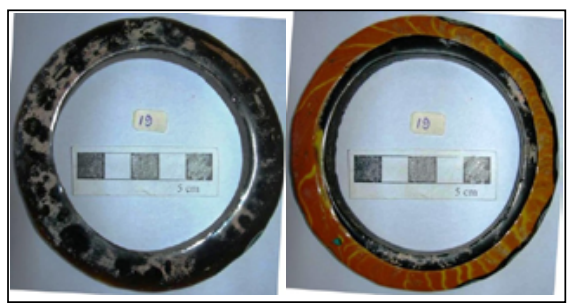

Fig. 33. Two glass bracelets.

Source: Museum of Erzurum.
Jewellery

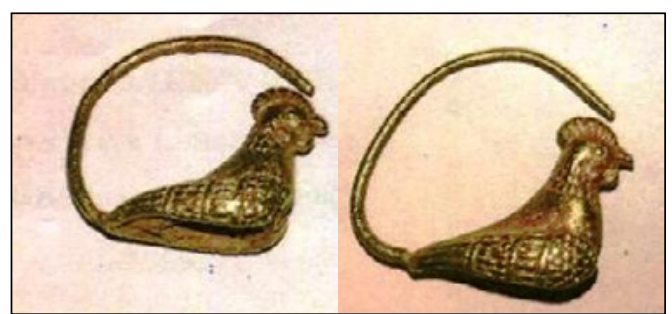

Fig. 34. Golden earrings.

Source: Museum of Izmir.

The realization is coarse in detail.

The upper part of the long loop and the blue stone set in a gold frame recall a pair of earrings from the Hellenistic period in the Metropolitan Museum (inv. no. 1995.539.11 $\mathrm{a}, \mathrm{b})$. The figure on the disc reminds depictions of the Hellenistic-Roman period (Von Bothmer et al. 1987: 307, no. 184).

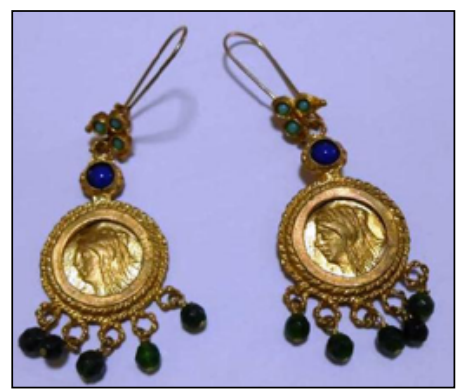

Fig. 35. Golden earrings with precious stones. Source: Museum of Batman.

\section{Instrumenta}

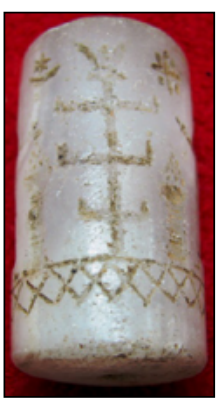

Fig. 36. A cylinder seal. Acquired from Bilal Kele凹. Source: Museum of Bolu. 
It looks like a Sumerian cylinder seal, but the image is not correct.

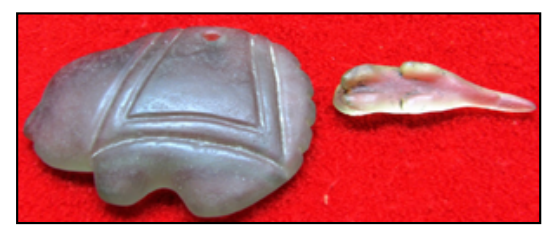

Fig. 37. Two gemelogical ornaments. Acquired from Abdülkudüs Şen.

Source: Museum of Bolu.

Their shape is not adequate.

Shapes and sizes are typically modern, likethe gems of the 18th and 19th centuries. In some cases, the execution is completely different from the ancient models.

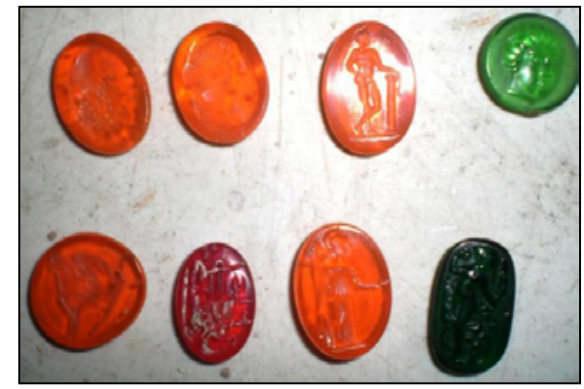

Fig. 38. Gems.

Source: Museum of Izmir.

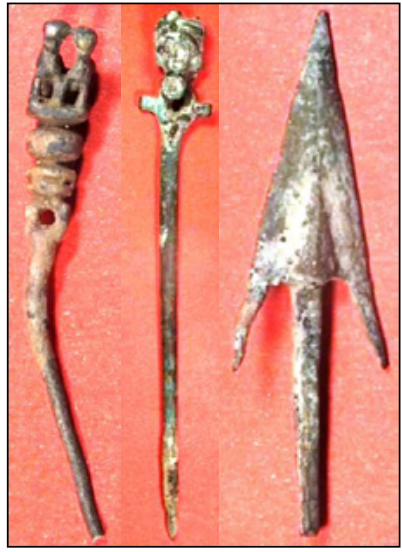

Fig. 39. Two bronze pins and an arrowhead. Source: Museum of Van.
Urartian bronze pins have a different look, and Anatolian arrows usually have a completely different shape.

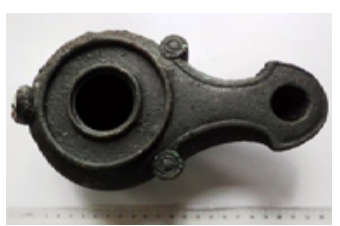

Fig. 40. A "Roman" bronze lamp. L $23 \mathrm{~cm}$.

Source: Museum of Anatolian Civilizations at Ankara.

Similar to the lamps and double volute from Mahdia; but too bright, too long and lacking patina.

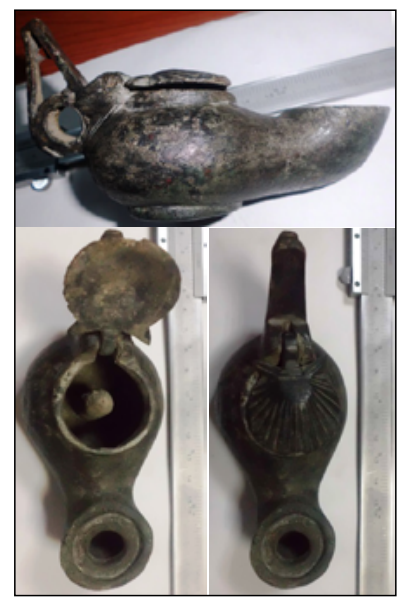

Fig. 41. A "Late Antique" bronze lamp. H $4.5 \mathrm{~cm}$, L $12 \mathrm{~cm}$, body r $5 \mathrm{~cm}$, weight 346.59 gr.

Source: Museum of Izmir.

The grip does not correspond exactly to those of ancient oil lamps.

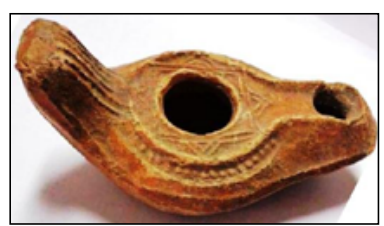

Fig. 42. A "Late Antique" terracotta lamp.

Source: Museum of Anatolian Civilizations at Ankara. 
Lamp with a tongue-shaped grip, inspired by popular lamps, such as Waagé (1948), Type 53, Kennedy (1963), Type 10 and Sodini et al. (1980), Type 1, which are dated to the sixth century A.D. The shape is similar; somewhat different is the decoration around the infundibulum. The type of material and the treatment of outer surface is different than the originals.

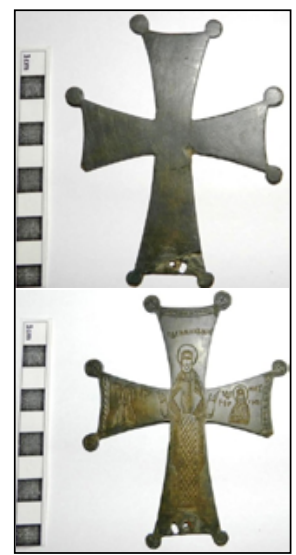

Fig 43. An "early Byzantine" bronze cross. Source: Museum of Sakarya.

This should be the figure of St. George, but the script was done by someone who does not know ancient Greek, and the side bust depicts the Madonna, even though we would expect the image of Christ at the center. The modern artist did not understand the models as seen in the necks and hands. The dress is too schematic and geometric. The incision (made by a drill or another tool) has left a flat and wide furrow and is extremly uncertain.

\section{Coins}

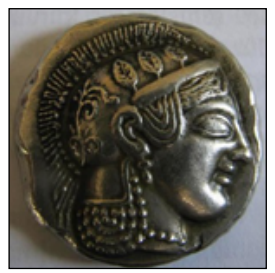

Fig. 44. Attica-Athens, AR tetradrachm, after 449 B.C. Source: Museum of Balıkesir.
Obv: Head of Athena on the right, wearing helmet, ornamented with vine scrolls and laurel leaves. Too wide; instead of $24 \mathrm{~mm}$ in diameter, it is $35 \mathrm{~mm}$. It has also different laurel leaves, of the tendril and of the dots under the helmet. Instead of a round earring, she has a bunchshaped one.

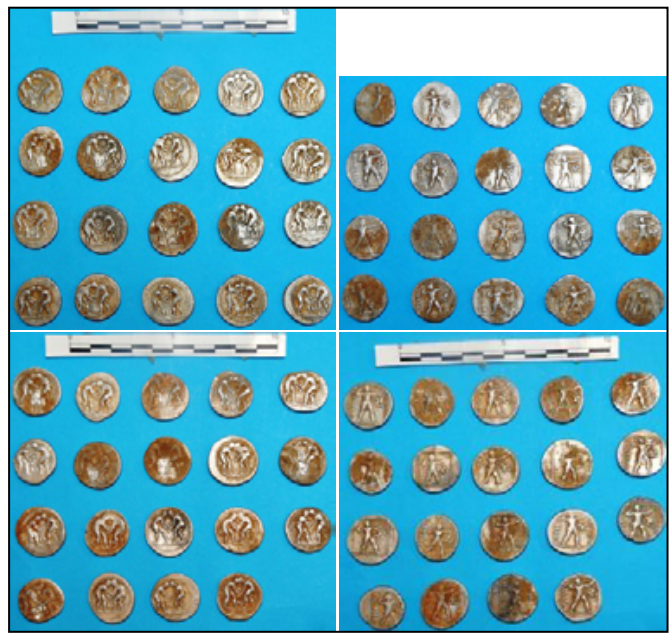

Fig. 45. 39 AR staters of Aspendos in Pamphylia between 370-325 B.C. R $21 \mathrm{~mm}$, weight - no. 1: $10.33 \mathrm{gr}$, no. 6: 10.83 gr, no. 21: 10.98 gr, and no. 26: 10.91 gr.

Source: Museum of Izmir.

Obv: Two wrestlers grappling. In almost all the examples they have a nonreadable facial feature and musculature; in many cases the transition from the torso to the legs is made in a very strange manner. They often repeated letters AA.

Rev: In left field a Greco-Pamphylian inscription "EST $\Phi E \triangle I I U \Sigma$ "; the slinger in throwing stance call to mind physical achievement glorified by Olympic events. In the right field a triskeles of human legs (badge of the city); below that a club of Hercules and part of the $\Phi$. Often the triskeles' position - variable in the original coins - is not correct; sometimes it lacks the right vertical line of points and the legend contains erros. 


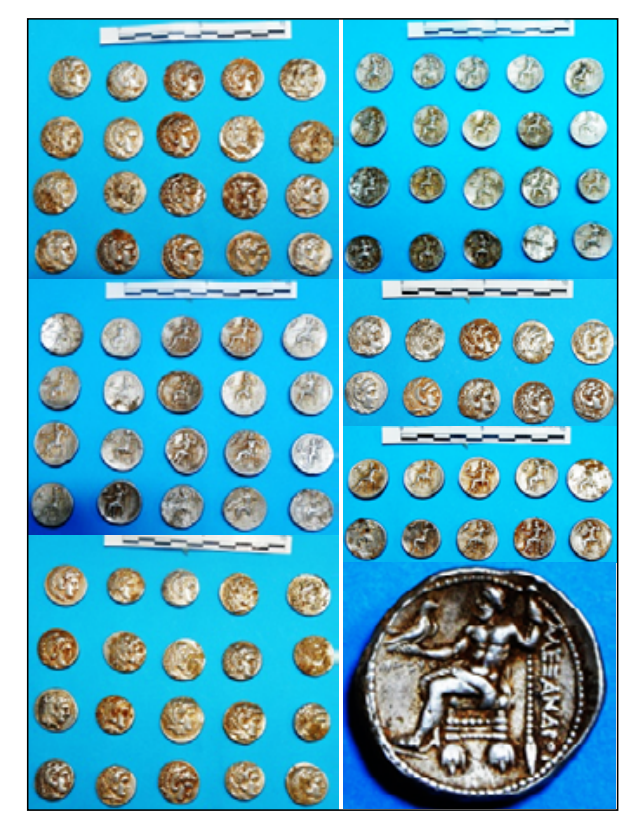

Fig. 46. 51 AR tetradrachms of Alexander the Great. R $23 \mathrm{~mm}$, weight - no. 1: $17.10 \mathrm{gr}$, no. 6: $17.14 \mathrm{gr}$, no. 21: 17.10 gr, no. 25: 17.20 gr, and no. 41: 17.13 gr.

Source: Museum of Izmir.

Obv: Alexander the Great as Hercules with a lion skin. The following errors are observed: schematic yield of the eye (= delta); lack of understanding of the head of a lion and his imperfect reproduction; summary yield of the hair.

Rev: In the field "A $\Lambda$ E $\Xi A N \triangle P O Y$ ", Zeus Aitophorus seated, holding an eagle in his outstretched hand. Sometimes Zeus' neck and the knot on top of the god's head are missing. In some coins the throne legs are ridiculous.

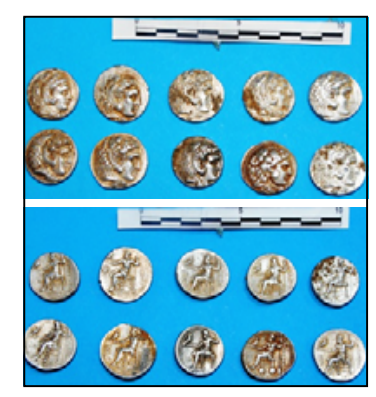

Fig. 47. 9 AR tetradrachms of Philippus Arridaius. R 22-23 mm, weight - no. 1: $17.16 \mathrm{gr}$, and no. 6: $17.09 \mathrm{gr}$. Source: Museum of Izmir.
Obv: Alexander the Great as Hercules with a lion skin.

Rev: In the field "BA $\mathrm{I} \Lambda \mathrm{I} \Omega \Sigma$ " and "ФІ $\Lambda$ ІППОҮ", Zeus Aitophoros is seated, holding an eagle in his outstretched hand.

In some specimens the lion's skin is different; as well as Zeus' muscles and the design of the throne. The legend is incorrect.

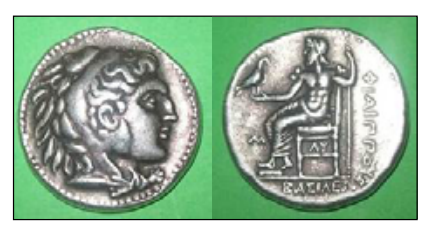

Fig. 48. A AR tetradrachm of Philippos Arridaius. Same obv. and rev. as no. 50.

Source: Museum of Aksaray.

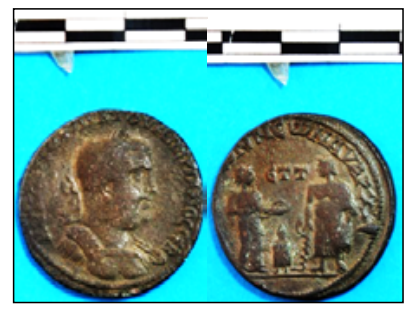

Fig. 49. Bronze coin of Aigeai in Cilicia during the era of Valerianus I (A.D. 253-260). R $31 \mathrm{~mm}$, weight: $19.47 \mathrm{gr}$.

Source: Museum of Izmir.

\section{Obv.: AY KAI POY $\Lambda \mathrm{IK}$}

OYA $\Lambda$ EPIANOC CEB.

Rev.: Hygeia, Asclepius, Telesphorus, [АІГIE]WN NES NAPXIC and the year ETT.

Fake details in the portrait in the lip and orbit design.

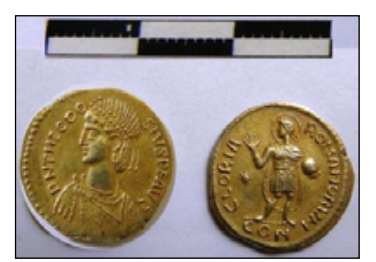

Fig. 50. Solidus of Theodosius II (A.D. 402-450).

Source: Museum of Mersin. 
Archaeological Fakes and Forgeries in Turkey

R. Museu Arq. Etn., 36: 1-21, 2021.

Obv.: DN THEODOSIVS PF AVG. Clearly a counterfeit because of different rendering of the hair and eye, and different output of his garment.

Rev:: GLORIA ROMANORVM eserg. CON. Different trend of the mantle, which hangs from the right arm or the globe; different shapes of the letters ${ }^{14}$.

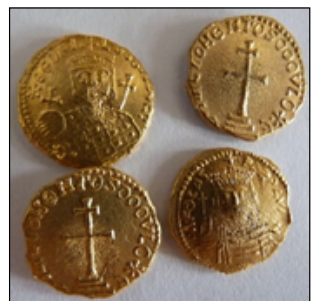

Fig. 51. Two golden coins of Empress Irene (A.D.797802) and Emperor Focas (602-610).

Source: Museum of Balıkesir.

Obv:: EIRINH BASILISSH. The portrait of the empress was not correctly represented, wearing loros and crown with pinnacles and pendilia; the legend is erroneous and not intelligible.

Rev.: dN FOCAS PERP AVC. The portrait of the emperor, wearing loros and a crown with pinnacles and pendilia, is wrong.

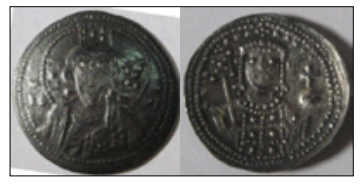

Fig. 52. Tetarteron nomisma of Alexius Comnenus (A.D. 1081-1118, struck 1081-1087).

Source: Museum of Akşehir.

Obv.: Facing bust of Christ Pantokrator.

Rev.: Facing bust of Alexius I Comnenus, crowned, holding cruciform scepter and globus cruciger. The legend is not legible.

14 On Byzantine counterfeit coins and their determination through non-destructive archaeometric analysis cf. Aydın \& Mutlu (2012).

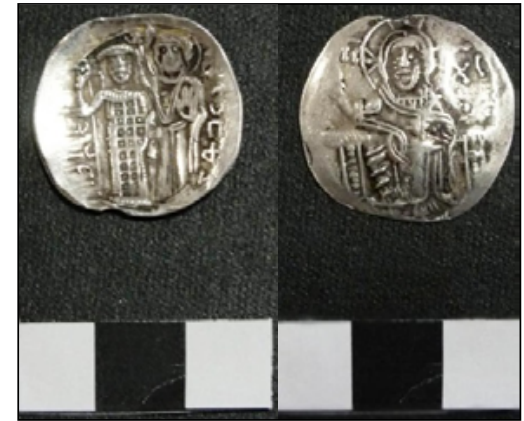

Fig. 53. A silver coin of Emperor Andronicus III Paleologus (A.D. 1328-1341).

Source: Museum of Uşak.

Obv.: St. Demetrius on the right, and Andronicus III on the left.

Rev: IC XC across field, Christ enthroned.

Lack of understanding of the drapery; inaccurate rendering of the sides of the throne.

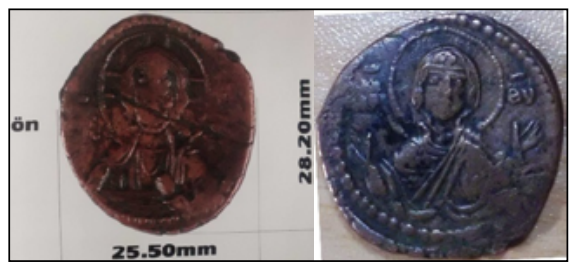

Fig. 54. Class G bronze anonymous follis of Romanus IV, Diogenes (A.D. 1068-1071).

Source: Museum of Izmir.

Constantinople mint.

Obv: Bust of Christ, nimbate, facing foward, wearing nimbus cruciger, pallium and colobium, raising right in benediction, scroll in left hand, on the left IC, on the right XC, border of large pellets, all within a circle of large dots.

Rev: Bust of the Virgin Orans facing foward, nimbate and wearing pallium and maphorium, on the left MP, on the right $\Theta \mathrm{V}$; within a circle of large pellets.

At the Christ' bust there are some visible errors in the drapery and scroll; confusion at the bust of the Virgin Mary on the right side.

Similar to the coinage of Saladin or Ayyubids. The legend is not readable on the edge. 


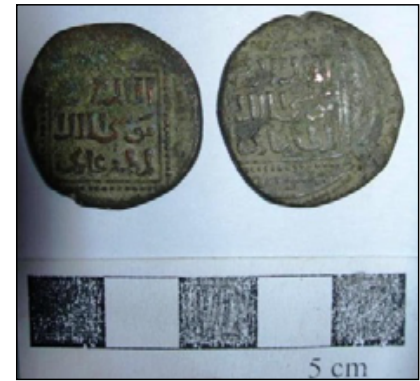

Fig. 55. A bronze Islamic Medieval coin. Source: Museum of Erzurum.

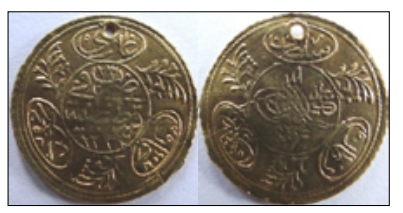

Fig. 56. An Ottoman golden coin (hayriye), Sultan Mahmud II (1808-1839; the original was struck in the year 1829). Acquired in Hopa, Artvin.

Source: Museum of Rize.
The original edge is lowerand does not present a series of triangular points protruding.

\section{Notes and acknowlegments}

Abbreviations: Inv. no.: inventory number; h: height; w: width; r: diameter; obv.: obverse, and rev.: reverse.

This collection was studied in 2014 by E. Lafl 1 by means of several authorizations, issued by the Turkish Ministry of Culture and Tourism (Museum of Izmir on February 23 $3^{\text {rd }}, 2012$; permit number B.16.0.K.V.M.4.35.00.01.155/604; and Museum of Ödemiş on January $6^{\text {th }}, 2012$; permit number B.16.0.K.V.M.4.35.74.00-155.01/21). Most of the photographs and map 1 were made by Dr Sami Patac1 (Ardahan) in 2014; some of the photos were taken from the website of the Turkish Ministry of Culture and Tourism (Figs. 3a, 4, 7, 9-12b, 16, 20, 23, 30-32 and 45).

LAFLI, E.; BUORA, M. Falsificações Arqueológicas na Turquia. R. Museu Arq. Etn., 36: 1-21, 2021.

Resumo: Este artigo discute a autenticidade arqueológica na Turquia dos pontos de vista científico-acadêmico e popular. Na Turquia, "falsificações arqueológicas" que um dia receberam pouca atenção tem criado debates públicos nos últimos cinco anos. Apesar de já conhecido, o problema não era abordado de forma constante em pesquisas científicas. É provável que ainda tenhamos um longo caminho até que os arqueólogos turcos sejam capazes de lidar com este assunto em termos científicos e aceitá-lo como um importante campo de estudos. Embora a Turquia seja um país-chave tanto para a descoberta de originais quanto para a produção de falsificações, sabemos pouco sobre quais materiais devem ser categorizados como réplicas ou falsificações, quais objetos foram classificados, quais materiais foram falsificados, por que e por quem. Estima-se que o número de falsificações expostas em museus locais seja muito alto, incluindo inúmeras lamparinas, moedas, objetos metálicos (especialmente de prata) e pedras preciosas. Nos mercados internacionais conhecemos várias tipos de objetos que foram falsificadas na Turquia, uma vez que é particularmente difícil distinguir entre moedas autênticas ou falsificações modernas, por exemplo. Diversos escândalos de falsificação em museus turcos surgiram nos últimos dez anos. Há duas explicações para os enganos: os administradores do museu não sabem nada sobre as falsificações, ou há outras razões pelas quais tais itens são apresentados como reais em exposições. Este artigo acompanha um catálogo amostral para a reanálise dos artefatos utilizando múltiplos critérios para a determinação de sua não autenticidade.

Palavras-chave: Falsificações arqueológicas; Réplicas; Imitações; Autênticos; Museus turcos. 


\section{References}

Accademia nazionale dei Lincei. 1899. Notizie degli scavi di antichità. Available from: <https://bit. ly/2Tyff5st>. Accessed on: Jul. 7, 2014.

Atwood, R. 2004. Stealing history: tomb raiders, smugglers, and the looting of the Ancient World. St. Martin's Press, New York.

Aydın, M. 2013a. Müze Kolleksiyonlarında Bulunan Antik Çağ Metal Eserlerinin Orjinalliğinin Korunmasinda Tahribatsı Arkeometrik Yöntemler. In: Proceedings of 3rd. ODTÜ Arkeometrik Çalıştayı. Türkiye Arkeolojisinde Metal: Arkeolojik ve Arkeometrik Çalışmalar, 2013, Ankara, 166-172.

Aydın, M. 2013b. Authenticity of Roman Imperial Age silver coins using non-destructive archaeometric techniques. Dissertation. Middle East Technical University, Ankara.

Aydın, M.; Mutlu, S. 2012. Bizans Dönemi'ne Ait Altın Sikke Orijinalliğinin Tespitinde Tahribatsız Arkeometrik ve Görsel Analiz Yöntemlerinin Kullanılması. In: Akyol, A.A.; Özdemir, K. (Eds.). Türkiye'de Arkeometrinin Ulu Çınarları. Homer Kitabevi, Istanbul, 97-106.

Babelon, E.; Blanchet, A. 1895. Catalogue des bronzes antiques de la Bibliothèque nationale. Eugène Piot Foundation, Paris.

Barresi, P. 2003. Province dell'Asia Minore. Costo dei marmi, architettura pubblica e committenza. L'Erma Di Bretschneider, Rome.

Blanchet, J.-A. 1896. Statuette d'Hermaphrodite. Revue archéologique 3: 160-162.

Bower, B. 2009. Archaeologists tracing the labyrinth of antiquities trafficking hope to shut it down, or at least slow it up. Science News 175: 20-23.

Bowman Proulx, B. 2011. Trafficking in Antiquities. In: Smith, C.; Zhang, S.; Barberet, R. (Eds.). Handbook of International Criminology. Routledge, New York, 192-199.
Bowman Proulx, B. 2013. Archaeological Site Looting in "Glocal" Perspective: Nature, Scope, and Frequency. AJA 117: 111-125.

Boyce, G.K. 1937. Corpus of Lararia of Pompei. Memoirs of the American Academy in Rome 14: 5-112.

Brodie, N.; Doole, J.; Renfrew, C. (Eds.). 2001. Trade in illicit antiquities: The destruction of the world's archaeological heritage. McDonald Institute, Cambridge.

Brodie, N.; Doole, J.; Watson, P. 2000. Stealing history. The illicit trade in cultural material. McDonald Institute, Cambridge.

Brodie, N.; Renfrew, C. 2005. Looting and the World's Archaeological Heritage: The Inadequate Response. Annual Review of Anthropology 34: 343-361.

Brodie, N.; Tubb, K. (Eds.). 2002. Illicit Antiquities: The Theft of Culture and the Extinction of Archaeology. Routledge, London.

Brumfield, S. 2018. How to spot fake cuneiform tablets. Friends of asor 6 . Available from: <https:// bit.ly/2TzwROe>. Access in: on: Jul. 4, 2020.

Bulgurlu, V.; İlaslı, A. 2003. Seals from the Museum of Afyon (Turkey). In: Cheynet, J.-C.; Sode, C. (Eds.). Studies in Byzantine Sigillography. Walter de Gruyter, Berlin, 131-149.

Colomban, P.; Laveaucoupet, R.; Milande, V. 2005. Onsite Raman Analysis of Kütahya Fritware. Journal of Raman Spectroscopy 36: 857-863.

Craddock, P. (Ed.). 2009. Scientific investigation of copies, fakes and forgeries. Oxford, Oxford University Press; Butterworth-Heinemann.

Hayes, J.W. 1972. Late Roman Pottery. London, British School at Rome.

Holtorf, C. 2013. On pastness: a reconsideration of materiality in archaeological object authenticity. Anthropological Quarterly 86: 427-443. 
Jones, M.; Craddock, P.T.; Barker, N. 1990. Fake? The art of deception. University of California Press, Los Angeles. Exhibition catalogue.

Kennedy, A. 1963. The Development of the Lamp in Palestine. Berytus 14: 67-115.

Lasteyrie du Saillant, R.-C. 1890. Album archéologique des musées de Province. E. Leroux, Paris.

Mezzasalma, A.M. et al. 2009. Ancient coins and their modern fakes: an attempt of physico-chemical unmasking. Mediterranean Archaeology and Archaeometry 9: 15-28.

Negbi, O. 1976. Canaanite Gods in Metal: An Archaeological Study of Ancient Syro-Palestinian Figurines. Tel Aviv University, Tel Aviv.

Neidhardt, M. 2010. Replik: Handarbeit in alter Tradition. Available from: <https://bit. ly/3jJZymd>. Accessed on: Jul. 7, 2014.

Pensabene, P. (Ed.). 1998. Marmi antichi II: cave e tecnica di lavorazione, provenienze e distribuzione. In: Proceedings of Seminario di archeologia e storia dell'arte graeca e romana dell'Università di Roma La Sapienza, 1998, Rome.

Porter, J.I. (Ed.). 2006. Classical pasts: the classical traditions of Greece and Rome. Princeton University Press, Princeton.

Pottier, E.; Reinach, S. 1888. La Necropole de Myrina. E. Thorin, Paris.

Renfrew, C. 2002. Loot, legitimacy, \& ownership. Bristol Classical Press, London.

Sayles, W.G. 2001. Classical deception: counterfeits, forgeries and reproductions of ancient coins. Krause, Iola.

Sismondo Ridgway, B. 2002. Hellenistic Sculpture 3: The Styles of ca. 100-31 B.C. University of Wisconsin, Madison.
Sodini, J.-P. et al. 1980. Déhès (Syrie du Nord). Campagnes I-III (1976-1978). Syria 57: 234-266.

Spier, J. 1990. Blinded with science: the abuse of science in the detection of false antiquities. The Burlington Magazine 132: 623-631.

T. C. Kültür ve Turizm Bakanlığı. 2019. Koleksiyonculardan Çalınan / Kaybolan Kültür Varlıkları. Available from: <https://bit. ly/3rHBbL4>. Accessed on: Apr. 7, 2020.

T.C. Kültür ve Turizm Bakanlığı. 1994. Marsyas Heykeli (A.B.D.). Available from: <https://bit. ly/2HORJ1R>. Accessed on: Mar. 11, 2021.

The Art Loss Register. 2007. Homepage. Available from: <https://bit.ly/3eqXPU4>. Accessed on: Abr. 7, 2020.

The British Museum. 2007. Explore the collection. Available from: $<$ https://bit.ly/3l4KlPf $>$. Accessed on: Jul. 7, 2014.

Uhlenbrock, J. 1990. The Coroplastic's Art. Greek Terracottas in Hellenistic World. Aristide D. Caratzas Pub., New Rochelle.

Von Bothmer, D. et al. 1987. Antiquities from the Collection of Christos G. Bastis, Emma Swan Hall. Philipp von Zabern, Mainz on Rhine.

Waagé, F.O. 1948. The Pottery. In: Elderkin, G.W. (Ed.). Antioch on the Orontes I: The Excavations of 1932 -1934. Princeton University, Princeton.

Walker, C.B.F. 1987. Reading the Past. Cuneiform. University of California Press, Berkeley.

Weis, A. 1992. The Hanging Marsyas and its copies: Roman Innovations in a hellenistic sculptural tradition. G. Bretschneider, Rome.

Witschel, C. 1995. Büste des Kaisers Marc Aurel. In: Stemmer, K. (Ed.). Standorte, Kontexte und Funktion antiker Skulptur. Ausstellungskatalog Berlin. Freunde \& Förderer der AbgussSammlung Antiker Plastik, Berlin, 257-262. 